\title{
IMPLEMENTASI PENCEGAHAN DAN PENGENDALIAN COVID-19 DI FASILITAS PELAYANAN KESEHATAN DI WILAYAH PROVINSI KALIMATAN TIMUR
}

\author{
Rahman Gumilar ${ }^{1}$, Robiana Modjo ${ }^{2}$, Riskiyana Sukandhi Putra $^{3}$,Dina Lusiana Setyowati ${ }^{4}$ \\ Departemen Keselamatan dan Kesehatan Kerja, Fakultas Kesehatan Masyarakat Universitas Indonesia ${ }^{1}$ \\ Direktorat Kesehatan Kerja dan Olahraga, Kementerian Kesehatan Republik Indonesia ${ }^{2}$ \\ Fakultas Kesehatan Masyarakat, Universitas Mulawarman, Kalimantan Timur ${ }^{3,4}$ \\ bian@ui.ac.id ${ }^{1}$
}

\begin{abstract}
Covid-19 cases in Indonesia until July 2021 have increased and reached the stage of The Restriction of Community Activities Level 4 in various regions of Indonesia. East Kalimantan province is a province outside Java island that topped the ranking of active cases of Covid-19 with positively confirmed cases of 109,814 people. This study aims to look at the implementation of Covid-19 prevention and control in Health Care Facilities in several regions in East Kalimantan Province based on KMK No. 413 and No. 327 year 2020. Research subjects include representatives of Type A, Type B and Type C hospitals as well as government-owned health centers and laboratories. The study was conducted in April 2021 until September 2021, research was conducted with observation methods and self assessment evaluation by key informants in each health care facility. The data was analyzed using univariate analysis. The results of the assessment of the implementation rate of Covid-19 prevention and control efforts obtained in hospital facilities by $86.3 \%$ with the category of Very Good, Puskemas with a value of $85.59 \%$, the Category of Excellent and laboratory get results of 57.46\% with the category Of Enough. Recommendations that can be made in hospitals are to improve risk communication and community involvement and patient management that occupies the lowest value. While in puskesmas is on the components of risk communication and community involvement, administration, finance and business continuity, as well as the mental health and psychosocial support components that still occupy components with poor value, while in the laboratory the human resources component occupies a critical component that must immediately get follow-up according to the results of this assessment instrument.
\end{abstract}

Keywords : Covid-19, community health center, hospital, Kalimantan Timur, KMK 413, KMK 327prevention

\begin{abstract}
ABSTRAK
Kasus Covid-19 di Indonesia hingga bulan Juli 2021 mengalami peningkatan dan mencapai tahapan Pemberlakuan Pembatasan Kegiatan Masyarakat Level 4 di berbagai wilayah Indonesia. Provinsi Kalimantan Timur merupakan provinsi di luar Pulau Jawa yang menduduki peringkat teratas kasus aktif Covid-19 dengan kasus terkonfirmasi positif sebesar 109.814 orang. Penelitian ini bertujuan untuk melihat implementasi pencegahan dan pengendalian Covid-19 pada Fasilitas Pelayanan Kesehatan di beberapa wilayah di Provinsi Kalimantan Timur berdasarkan KMK No 413 dan No 327 Tahun 2020. Subyek penelitian meliputi perwakilan Rumah Sakit Tipe A, Tipe B dan Tipe C serta Puskesmas milik pemerintah dan Laboratorium. Penelitian dilakukan pada bulan April 2021 sampai dengan bulan Sepember 2021, Penelitian dilakukan dengan metode observasi dan self assessment evaluation oleh informan kunci di setiap fasilitas pelayanan kesehatan. Data dianalisa menggunakan univariat analisis. Hasil penilaian tingkat implementasi upaya pencegahan dan pengendalian Covid-19 yang didapatkan pada fasyankes Rumah Sakit sebesar 86.3\% dengan kategori Sangat Baik, Puskemas dengan nilai 85.59\%, kategori Sangat Baik dan Laboratorium mendapatkan hasil $57.46 \%$ dengan kategori Cukup. Rekomendasi yang dapat dilakukan di Rumah Sakit adalah dengan meningkatkan komunikasi risiko dan keterlibatan masyarakat dan manajemen pasien yang menempati nilai yang paling rendah. Sedangkan di Puskesmas adalah pada komponen komunikasi risiko dan keterlibatan masyarakat, Administrasi, keuangan dan keberlangsungan bisnis, juga komponen kesehatan kerja kesehatan mental dan dukungan psikososial yang masih menempati komponen dengan nilai yang kurang baik, sedangkan di laboratorium
\end{abstract}


komponen sumber daya manusia menempati komponen kritikal yang harus segera mendapat tindaklanjut menurut hasil instrumen penilaian ini.

Kata Kunci : Covid-19, KMK, 413, KMK 327, Kalimantan Timur, Pengendalian, Puskesmas, Rumah Sakit

\section{PENDAHULUAN}

Penyakit Corona Virus Disease 2019 (Covid-19) yang muncul pada akhir tahun 2019 di Wuhan Cina merupakan penyakit yang teridentifikasi sebagai Virus Corona terbaru yang diberi nama sebagai Severe Acute Respiratory Syndrome Coronavirus 2 (SARS-CoV-2). Virus ini menjadi pusat perhatian bersama dikarenakan tingginya angka penyebaran virus yang cepat yang akhirnya menyebar ke seluruh Negara di Dunia. Virus yang memiliki tanda dan gejala gangguan pernafasan akut seperti demam, batuk dan sesak nafas, dengan masa inkubasi rata-rata 5-6 hari dan masa inkubasi terpanjang mencapai 14 hari. (Zhu, N; Zhang, D; Wang, 2019).

Indonesia juga mengalami hal yang sama dengan 211 Negara lainnya di dunia, dimana Indonesia telah mengalami lonjakan angka tertinggi pertama pada tanggal 18 Juni 2020 dengan jumlah kasus terkonfirmasi sebanyak 41.431 kasus, dan jumlah kasus meninggal tercatat sebanyak 2.339 kasus dengan Case Fatality Rate (CFR) 5,5\%. Setelah mengalami 1 tahun pandemi Covid19, Indonesia akhirnya mengalami lonjakan kedua COVID-19 di bulan Juli 2021, dengan angka lonjakan sebesar 3.532.5672 kasus terkonfirmasi dan angka positive rate sebesar $19,2 \%$ serta angka fatality rate sebesar 2,8\%. (Kemenkes, 2021).

Pada Jumlah Kasus Covid-19, Indonesia merupakan negara ke-14 tertinggi yang mempunyai kasus penambahan terbanyak kasus Covid-19 di dunia. Sedangkan untuk lingkup Asia Tenggara, Indonesia memiliki kasus kematian tertinggi dengan 100.636 kasus yang kemudian diikuti oleh Filipina dengan 28.231 kasus kematian dan Myanmar dengan 10.373 kasus kematian. Jika melihat dalam wilayah Indonesia, terdapat ada 6(enam) provinsi yang menyumbangkan angka Covid-19 tertinggi. 6 (enam) provinsi tersebut adalah DKI Jakarta (22,9\%), Jawa Barat $(17,5 \%$, Jawa Tengah $(11,2 \%)$, Jawa Timur $(9,2 \%)$, Kalimantan Timur $(3,5 \%)$ dan DI Yogyakarta (3,5\%). Dari 5 (enam) Provinsi tertinggi tersebut terlihat bahwa provinsi-provinsi tertinggi tersebut berasal dari pulau Jawa dan Kalimantan Timur adalah provinsi tertinggi yang berada di luar Pulau Jawa. (Satgas, 2021).

Provinsi Kalimantan Timur menjadi Provinsi tertinggi kelima di Indonesia dengan angka penambahan kasus Covid-19 terbanyak. Penambahan kasus tersebut sangat mempengaruhi kesiapan dan kemampuan wilayah dalam hal ini fasilitas kesehatan berupa Rumah Sakit Rujukan Covid-19 bagi masyarakat yang membutuhkan penanganan medis. Menurut Kemenkes, Bed Occupancy Rate (BOR) yang dimiliki Rumah Sakit Rujukan Covid-19 di Provinsi Kalimantan Timur tertinggi sebesar $77 \%$ setelah Provinsi Bali sebesar 78\%. (Satgas, 2021)

Peningkatan kasus pada lonjakan kedua memperlihatkan bahwa beratnya tugas yang diemban oleh para tenaga kesehatan sebagai garda terdepan memberikan dampak psikologi yang buruk bagi mereka yang bertugas di Rumah Sakit Rujukan Covid-19. Dampak psikologis yang dialami oleh tenaga kesehatan sesuai dengan laporan penelitian terdahulu yang menyampaikan bahwa kondisi wabah infeksi pernapasan yang akut telah memberikan beban psikologis pada para petugas kesehatan berupa kecemasan, depresi, serangan panik sampai dengan gejala psikotik. (Xiang et al., 2020)

Penelitian lainnya yang menggambarkan adanya gangguan psikologis pada para tenaga keseahtan garda terdepan dengan didapati sebanyak $71,5 \%$ tenaga kesehatan mengalami distress dalam melaksanakan tugas selama pandemi Covid-19 berlangsung. Pada penelitian ini juga ditemukan 50,4\% 
mengalami gejala depsresi dan $34 \%$ mengalami insomnia. (Lai et al., 2020)

Stres diakibatkan oleh beban kerja yang berlebihan dikarenakan banyaknya pasien Covid-19 yang harus ditangani diluar kesanggupan para tenaga kesehatan. Tidak sedikit para tenaga kesehatan yang akhirnya terpapar Covid-19 bahkan mendapatkan kondisi yang buruk hingga gugur dalam menjalankan tugas. Dukungan dari rumah sakit dibutuhkan oleh para tenaga kesehatan, dimana rumah sakit juga mengalami masa masa sulit dalam masa Pandemi Covid-19. Masalah yang dihadapi rumah sakit berupa menurunnya pendapatan, meningkatnya pengeluaran dan masalah sumber daya manusia. (Apriningsih et al., 2020)

Semua perhatian pemerintah Indonesia tertuju kepada upaya penanganan tingginya angka masyarakat terkonfirmasi Covid-19 dengan memaksimalkan fasilitas pelayanan kesehatan di setiap wilayah. Seperti diketahui, Rumah Sakit, Puskesmas dan Laboratorium Kesehatan merupakan ujung tombak dalam penanganan Covid-19 di Indonesia, dimana tenaga kesehatan yang bertugas didalam fasilitas pelayanan kesehatan tersebut adalah garda terdepan yang berhubungan kontak lansung dalam menangani pasien Covid-19. Sehingga perhatian pemerintah tidak hanya tertuju kepada memaksimalkan fasilitas pelayanan kesehatan namun juga tertuju kepada resiko besar yang dimiliki oleh tenaga kesehatan yang bertugas sebagai garda terdepan penanganan Covid-19.

Ikatan Dokter Indonesia (IDI) melaporkan tenaga dokter di Indonesia yang meninggal dunia sebanyak 54 dokter, selain itu, Persauan Perawat Nasional Indonesia (PPNI) juga ikut melaporkan bahwa tercatat sebanyak 445 perawat meninggal dunia akibat akibat pandemi Covid-19. (Dimas, 2021) Hal ini harus menjadi perhatian bahwa tenaga kesehatan termasuk dokter, perawat maupun tenaga kesehatan lainnya agar mendapatkan perlindungan dari pemerintah atau pihak manajemen rumah sakit bagi tenaga kesehatan yang dengan sukarela mengabdikan dirinya untuk melayani masyarakat bahkan sampai mengorbankan nyawanya demi membantu pemerintah dalam penanggulangan pandemi Covid-19.

Sebagaimana diketahui Provinsi Kalimantan Timur telah ditetapkan oleh Presiden Joko Widodo Sebagai Pusat Pemerintahan Indonesia yang akan datang. (Nugroho \& Damayanti, 2019). Pada kenyataannya, Provinsi Kalimantan Timur masih mempunyai fasilitas kesehatan yang masih minim jika dibandingkan dengan fasilitas kesehatan yang berada di pulau Jawa. Oleh karena itu, Provinsi Kalimantan Timur sangat memerlukan perhatian terkait pelayanan kesehatan yang disediakan melihat fenomena cepatnya penularan Covid-19. (Paramita et al., 2020).

Tenaga kesehatan dan non kesehatan yang melaksanakan tugas pada fasilitas pelayanan kesehatan mempunyai resiko tinggi yang dapat mengakibatkan tertular akibat pekerjaan yang dilakukan, oleh karena itu Kementerian Kesehatan menetapkan Keputusan Menteri Kesehatan Republik Indonesia No. HK.01.07/Menkes/327/2020 tentang Penetapan Corona Virus Disease2019 (Covid-19) Akibat Kerja yang Spesifik pada Pekerjaan Tertentu. Corona Virus Disease 2019 (Covid-19) merupakan penyakit akibat kerja yang disebabkan oleh faktor biologi ditempat kerja dimana ada paparan langsung dengan para pekerja.

Kementerian Kesehatan Republik Indonesia telah memberikan pedoman yang menjadi acuan bagi fasilitas pelayanan kesehatan dan tenaga kesehatan yang dituangkan dalam kebijakan Keputusan Menteri Kesehatan Nomor HK.01.07/Menkes/413/2020 tentang Pedoman Pencegahan dan Pengendalian Coronavirus Diseases 2019 (Covid-19). Pedoman ini disusun berdasarkan evidence based mengenai penanganan Covid-19 untuk memandu tenaga kesehatan meminimalisasi tingkat resiko terjadi pajanan infeksi serta mencegah dan memutuskan penularan Covid19. Adapun upaya yang perlu diterapkan pada fasilitas pelayanan kesehatan adalah kewaspadaan isolasi, pengendalian administrasi, pendidikan dan pelatihan, 
pencegahan dan pengendalian infeksi pra rujukan dan pencegahan infeksi pemulasaraan jenazah. Bagi fasilitas pelayanan kesehatan dan tenaga kesehatan menjalankan pedoman No. HK.01.07/Menkes/413/2020 adalah kewajiban untuk melindungi pasien dan petugas kesehatan untuk memutus rantai penularan Covid-19.

Penelitian ini bertujuan untuk mengetahui upaya yang dilakukan fasilitas pelayanan kesehatan yang ada di beberapa wilayah provinsi Kalimantan Timur dalam mengendalikan dan memutuskan rantai penularan Covid-19 serta upaya menjaga para tenaga kesehatan yang beresiko tinggi dalam menjalankan tugas sebagai garda terdepan. Penelitian ini mengacu kepada Kepetusan Menteri Kesehatan Republik Indinesia No. HK.01.07/Menkes/327/2020 dan No. HK.01.07/Menkes/413/2020 sebagai pedoman melihat upaya-upaya dalam penanganan Covid-19 di Fasilitas Pelayanan Kesehatan di beberapa wilayah provinsi Kalimantan Timur.

\section{METODE}

Penelitian dilakukan di Provinsi Kalimantan Tmur pada Rumah Sakit AWS Provinsi Kalimantan Timur, Rumah Sakit IAM Kota Samarinda, Rumah Sakit AMP Kutai Kertanegara, Puskesmas L Kota Samarinda, Puskesmas KI dan Laboratorium Kesda Kalimantan Timur. Penelitian dilakukan pada bulan April 2021 sampai dengan bulan Sepember 2021, Penelitian dilakukan dengan metode observasi dan self assessment evaluation oleh informan kunci di setiap fasilitas pelayanan kesehatan.

Instrumen yang digunakan mengacu kepada Keputusan Menteri Kesehatan Republik Indonesia Nomor HK.01.07/Menkes/327/2020 tentang Penetapan Corona Virus Disease 2019 (Covid-19) Akibat Kerja sebagai Penyakit Akibat Kerja yang Spesifik pada Pekerjaan Tertentu dan berdasarkan Keputusan Menteri Kesehatan Republik Indonesia Nomor HK.01.07/Menkes/413/2020 tentang Pedoman Pencegahan dan Pengendalian
Coronavirus Diseases 2019 (Covid-19). Instrumen penelitian juga mengacu pada instrument Hospital readiness Checklist yang dikeluarkan oleh WHO dan dikembangkan oleh PAKKI (Perhimpunan Ahli Kesehatan Kerja Indonesia). Penilaian tingkat implementasi pencegahan dan pengendalian akan memiliki kategori kurang untuk skor 040, cukup untuk skor 41-59, baik untuk skor 60-79 dan sangat baik 80 ke atas.

\section{HASIL}

Penilaian pada penelitian ini mengacu kepada Keputusan Menteri Kesehatan Republik Indonesia No. HK.01.07/Menkes/327/2020 tentang Penetapan Corona Virus Disease 2019 (Covid-19) Akibat Kerja sebagai Penyakit Akibat Kerja yang Spesifik pada Pekerjaan Tertentu dan berdasarkan Keputusan Menteri Kesehatan Republik Indonesia Nomor HK.01.07/Menkes/413/2020 tentang Pedoman Pencegahan dan Pengendalian Coronavirus Diseases 2019 (Covid-19) ditampilkan melalui tabel berikut :

Tabel 1. Rekap Penilaian Upaya Perlindungan Tenaga Kesehatan dan Pekerja Tenaga Kesehatan pada Situasi Pandemi Covid-19

\begin{tabular}{|c|c|c|c|}
\hline Fasyankes & $\begin{array}{c}\text { Jumla } \\
\text { h } \\
\text { Skor }\end{array}$ & Nilai & $\begin{array}{c}\text { Katego } \\
\text { ri }\end{array}$ \\
\hline Rumah Sakit AWS & 875 & $\begin{array}{c}86,6 \\
3\end{array}$ & $\begin{array}{l}\text { Sangat } \\
\text { Baik }\end{array}$ \\
\hline $\begin{array}{l}\text { Rumah Sakit IAM Kota } \\
\text { Samarinda }\end{array}$ & 865 & $\begin{array}{c}85,6 \\
4\end{array}$ & $\begin{array}{l}\text { Sangat } \\
\text { Baik }\end{array}$ \\
\hline $\begin{array}{l}\text { Rumah Sakit AMP } \\
\text { Kutai Kartanegara }\end{array}$ & 875 & $\begin{array}{c}86,6 \\
3\end{array}$ & $\begin{array}{l}\text { Sangat } \\
\text { Baik }\end{array}$ \\
\hline $\begin{array}{l}\text { Puskesmas L Kota } \\
\text { Samarinda }\end{array}$ & 720 & $\begin{array}{c}84,7 \\
1\end{array}$ & $\begin{array}{l}\text { Sangat } \\
\text { Baik }\end{array}$ \\
\hline Puskesmas KI & 735 & $\begin{array}{c}86,4 \\
7\end{array}$ & $\begin{array}{l}\text { Sangat } \\
\text { Baik }\end{array}$ \\
\hline $\begin{array}{l}\text { Laboratorium } \\
\text { Kesehatan Daerah } \\
\text { Kalimantan Timur }\end{array}$ & 385 & $\begin{array}{c}57,4 \\
6\end{array}$ & Cukup \\
\hline
\end{tabular}

Pada Tabel 1 terlihat bahwa hampir semua Fasilitas Pelayanan Kesehatan telah memiliki nilai dengan kategori yang sangat 
baik, namun Laboratorium Kesehatan Daerah Kalimantan Timur memiliki nilai dengan kategori cukup.

Peneliti akan memperlihatkan hasil setiap nilai yang dihitung di setiap klasifikasi 3 fasilitas pelayanan kesehatan, yaitu Rumah Sakit, Puskesmas dan Laboratorium. Penilaian akan memperlihatkan nilai-nilai yang dihasilkan di setiap elemen penilaian.

\section{Rumah Sakit}

Penilaian Upaya Perlindungan Tenaga Kesehatan dan Pekerja di Rumah Sakit pada situasi Pandemi Covid-19 akan memperlihatkan nilai pada 13 elemen yang dihitung pada 3(tiga) Rumah Sakit.

Table 2. Rekap Penilaian 13 Elemen Upaya Perlindungan Tenaga Kesehatan dan Pekerja Tenaga Kesehatan pada Situasi Pandemi Covid-19 pada 3 (tiga) Rumah Sakit

\begin{tabular}{|c|c|c|c|}
\hline \multirow[b]{2}{*}{ Elemen Penilaian } & \multicolumn{3}{|c|}{ Skor Tiap Elemen } \\
\hline & $\begin{array}{c}\text { RS } \\
\text { AWS }\end{array}$ & $\begin{array}{c}\text { RS } \\
\text { IAM }\end{array}$ & $\begin{array}{l}\text { RS } \\
\text { AMP }\end{array}$ \\
\hline Umum & 90 & 100 & 90 \\
\hline $\begin{array}{l}\text { Kepemimpinan dan Sistem } \\
\text { Manajemen Insiden }\end{array}$ & 55 & 60 & 60 \\
\hline $\begin{array}{l}\text { Koordinasi dan } \\
\text { Komunikasi }\end{array}$ & 60 & 50 & 55 \\
\hline $\begin{array}{l}\text { Surveilans dan } \\
\text { Manajemen Informasi }\end{array}$ & 40 & 55 & 45 \\
\hline $\begin{array}{l}\text { Komunikasi Risiko dan } \\
\text { Keterlibatan Masyarakat }\end{array}$ & 20 & 25 & 35 \\
\hline $\begin{array}{l}\text { Administrasi, Keuangan, } \\
\text { dan Keberlanjutan Bisnis }\end{array}$ & 60 & 60 & 80 \\
\hline Sumber Daya Manusia & 45 & 60 & 55 \\
\hline Surge Capacity & 25 & 40 & 50 \\
\hline $\begin{array}{l}\text { Keberlanjutan Layanan } \\
\text { Pendukung Esensial }\end{array}$ & 55 & 55 & 60 \\
\hline Manajemen Pasien & 30 & 30 & 35 \\
\hline $\begin{array}{l}\text { Kesehatan Kerja, } \\
\text { Kesehatan Mental, dan } \\
\text { Dukungan Psikososial }\end{array}$ & 60 & 60 & 55 \\
\hline $\begin{array}{l}\text { Identifikasi dan Diagnosis } \\
\text { Cepat }\end{array}$ & 60 & 60 & 60 \\
\hline $\begin{array}{ll}\text { Pencegahan dan } \\
\text { Pengendalian Infeksi }\end{array}$ & 275 & 210 & 195 \\
\hline JUMLAH & 875 & 865 & 875 \\
\hline
\end{tabular}

Pada penjabaran 13 elemen diatas, terlihat bervariasi penilaian di setiap elemen, pada elemen umum, elemen administrasi, keuangan, dan keberlanjutan bisnis, elemen identifikasi dan diagnosis cepat dan elemen pencegahan dan pengendalian infeksi mendapatkan kategori baik dan sangat baik pada 3 rumah sakit site penelitian. Sedangkan pada elemen surveilans dan manajemen informasi, elemen komunikasi risiko dan keterlibatan masyarakat, elemen surge capacity, dan elemen manajemen pasien mendapatkan kategori kurang.

\section{Puskesmas}

Penilaian Upaya Perlindungan Tenaga Kesehatan dan Pekerja di Puskesmas pada situasi Pandemi Covid-19 akan memperlihatkan nilai pada 12 elemen yang dihitung pada 2 (dua) Puskesmas.

Table 3. Rekap Penilaian 12 Elemen Upaya Perlindungan Tenaga Kesehatan dan Pekerja Tenaga Kesehatan pada Situasi Pandemi Covid-19 pada 2 (dua) Puskesmas

\begin{tabular}{|c|c|c|}
\hline \multirow[b]{2}{*}{ Elemen Penilaian } & \multicolumn{2}{|c|}{$\begin{array}{l}\text { Skor Tiap } \\
\text { Elemen }\end{array}$} \\
\hline & $\begin{array}{c}\text { Puske } \\
\text { smas } \\
\text { L }\end{array}$ & $\begin{array}{l}\text { Puskes } \\
\text { mas KI }\end{array}$ \\
\hline Umum & 90 & 70 \\
\hline $\begin{array}{l}\text { Kepemimpinan dan Sistem } \\
\text { Manajemen Insiden }\end{array}$ & 70 & 70 \\
\hline Koordinasi dan Komunikasi & 45 & 40 \\
\hline $\begin{array}{l}\text { Surveilans dan Manajemen } \\
\text { Informasi }\end{array}$ & 45 & 45 \\
\hline $\begin{array}{l}\text { Komunikasi Risiko dan } \\
\text { Keterlibatan Masyarakat }\end{array}$ & 20 & 15 \\
\hline $\begin{array}{l}\text { Administrasi, Keuangan, dan } \\
\text { Keberlanjutan Bisnis }\end{array}$ & 20 & 50 \\
\hline Sumber Daya Manusia & 65 & 55 \\
\hline $\begin{array}{l}\text { Keberlanjutan } \\
\text { Pendukung Esensial }\end{array}$ & 35 & 55 \\
\hline Manajemen Pasien & 25 & 20 \\
\hline $\begin{array}{lll}\text { Kesehatan } & \text { Kerja, } & \text { Kesehatan } \\
\text { Mental, } & \text { dan } & \text { Dukungan } \\
\text { Psikososial } & & \end{array}$ & 20 & 30 \\
\hline Identifikasi dan Diagnosis Cepat & 35 & 25 \\
\hline $\begin{array}{l}\text { Pencegahan dan Pengendalian } \\
\text { Infeksi }\end{array}$ & 250 & 260 \\
\hline JUMLAH & 720 & 735 \\
\hline
\end{tabular}

Pada penjabaran 12 elemen diatas, terlihat penilaian di setiap elemen, pada 
elemen umum, elemen kepemimpinan dan sistem manajemen insiden, dan elemen pencegahan dan pengendalian infeksi mendapatkan kategori "Baik" dan "Sangat Baik" pada 2 (dua) Puskesmas.

Penilaian yang mendapatkan kategori "Kurang" di 2 (dua) puskesmas terdapat pada elemen koordinasi dan komunikasi, elemen surveilans dan manajemen informasi, elemen komunikasi risiko dan keterlibatan masyarakat, elemen administrasi, keuangan, dan keberlanjutan bisnis, elemen keberlanjutan layanan pendukung esensial dan manajemen pasien, elemen kesehatan kerja, kesehatan mental, dan dukungan psikososial dan elemen identifikasi dan diagnosis cepat.

\section{Laboratorium}

Penilaian Upaya Perlindungan Tenaga Kesehatan dan Pekerja di Laboratorium pada Situasi Pandemi Covid-19 akan memperlihatkan nilai pada 12 elemen yang dihitung pada 1(satu) Laboratorium.

\section{Tabel 4. Rekap Penilaian 6 Elemen Upaya Perlindungan Tenaga Kesehatan dan Pekerja Tenaga Kesehatan pada situasi Pandemi Covid-19 pada 1 (satu) Laboratorium}

\begin{tabular}{lc}
\hline \multicolumn{1}{c}{ Elemen Penilaian } & \multicolumn{1}{c}{$\begin{array}{c}\text { Skor Tiap } \\
\text { Elemen }\end{array}$} \\
\cline { 2 - 2 } & $\begin{array}{c}\text { Laboratorium } \\
\text { Daerah }\end{array}$ \\
\hline $\begin{array}{l}\text { Kepemimpinan dan Sistem } \\
\text { Manajemen Bencana }\end{array}$ & 50 \\
Keselamatan dan Kesehatan Kerja & 155 \\
$\begin{array}{l}\text { Manajemen Risiko } \\
\text { Pencegahan dan Pengendalian }\end{array}$ & 30 \\
$\begin{array}{l}\text { Kontaminasi } \\
\text { Koordinasi dan Komunikasi }\end{array}$ & 110 \\
Sumber Daya Manusia & 40 \\
\hline \multicolumn{1}{c}{ JUMLAH } & 0 \\
\hline
\end{tabular}

Pada penjabaran 6 elemen diatas, terlihat variasi penilaian di setiap elemen, pada elemen keselamatan dan kesehatan kerja, elemen pencegahan dan pengendalian kontaminasi, Laboratorium Darerah mendapatkan kategori "Sangat Baik". Sedangkan pada elemen kepemimpinan dan sistem manajemen bencana, elemen manajemen resiko, elemen koordinasi dan komunikasi dan elemen sumber daya manusia terlihat elemen-elemen tersebut mendapatkan nilai "Kurang" pada Labaoratorium Daerah.

\section{PEMBAHASAN}

Dalam menghadapi Pandemi Covid-19 diperlukan kesiapsiagaan yang strategis dan rencana penanggulanganan dengan menguraikan langkah-langkah dengan pendekatan kesehatan masyarakat. Diharapkan rencana-rencana yang dipersiapkan dapat dengan cepat mengidentifikasi tindakan yang tepat. Rencana yang disusun akan membantu memandu dan menyelaraskan semua pihak dalam menanggulangani pandemi Covid-19.

Rencana Strategis Covid-19 dibutuhkan dengan mengacu kepada berbagai aspek pandemi Covid-19 untuk menanggapi krisis dengan mengambil langkah-langkah untuk memperkuat sistem kesehatan. Rencana strategis dapat disusun pada fasilitas layanan kesehatan seperti rumah sakit, puskesmas, laboratorium kesehatan dan fasilitas kesehatan lainnya.

Setiap fasilitas layanan kesehatan harus memiliki langkah-langkah dalam menghadapai penanggulangan pandemi Covid-19 bervariasi tergantung kepada peran masing-masing fasilitas layanan kesehatan. Peran-peran penanganan Covid-19 tersebut meliputi identifikasi awal atas kasus yang membutuhkan perawatan, pemberian pengobatan, pemberian perawatan rutin pelayanan kesehatan esensial, pencegahan pasien tertular Covid-19 di fasilitas layanan kesehatan dan pemberian informasi mengenai Covid-19

WHO telah membuat daftar kesiapan rumah sakit atau disebut dengan Rapid Hospital Readiness Checklist yang dikembangkan berdasarkan respon strategis Covid-19 dan rencana kesiapsiagaan. Daftar ini dirancang agar mudah dipergunakan dengan mempertimbangkan sumber daya manusia yang bekerja sebagai garda terdepan 
penanggulanganan Covid-19. Daftar kesiapan yang dirancang oleh WHO tersebut mempertimbangkan masalah-masalah yang timbul seperti perawatan pasien dengan gejala berat dan akut, pelayanan laboratorium yang dibutuhkan, kebutuhan darah, pendistribusian obat, pengelolaan informasi, kebutuhan sumber daya manusia, tantangan keamanan, perlindungan terhadap petugas kesehatan, kesehatan mental dan psikosial untuk semua petugas kesehatan.

Berdasarkan Rapid Hospital Readiness Checklist tersebut, penelitian ini mengadopsi Cheklist tersebut untuk mengetahui gambaran kesiapan fasilitas pelayanan kesehatan di Provinsi Kalimantan Timur.

\section{Elemen 1 : Kepemimpinan dan Sistem Manajemen Insiden}

Pada elemen Kepemimpinan dan Sistem Manajemen Insiden, memperlihatkan fasilitas pelayanan kesehatan di Provinsi Kalimantan sudah berfungsi dengan baik dan mempunyai manajemen kedaruratan yang efektif.

Sistem manajemen insiden dikembangkan oleh WHO untuk mengelola respon terhadap kejadian terkait kesehatan masyarakat, keadaan darurat dan untuk memastikan fasilitas pelayanan kesehatan mengikuti standarisasi terbaik dalam menjalankan fungsi manajemen darurat. Adapun fungsi yang digunakan dalam Manajemen Insiden adalah : kepemimpinan, koordinasi antara mitra, informasi dan perencanaan, pemberian pelayanan kesehatan, keahlian bersifat teknis, dukungan pemberian pelayanan dan logistik, serta keuangan dan administrasi. (WHO, 2020c).

Fungsi kepemimpinan adalah bertanggungjawab atas strategi kepemimpinan dan pengawasan sehari-hari serta manajemen respon terhadap keadaaan darurat. Fungsi dijalankan dengan memberikan otoritas kepada seorang pemimpin dalam mencari dan menyepakati prioritas dan tujuan sebagai bentuk respon dalam keadaan darurat secara konsisten dengan mengutamakan prinsip kemanusiaan. (WHO, 2017)

Situasi Kepemimpinann dan Sistem Manajemen Insiden pada fasilitas pelayanan kesehatan di Provinsi Kalimantan Timur telah memperlihatkan komitmen dalam menerapkan kebijakan yang mendukung penanggulangan pandemi Covid-19 yang mengedepankan manajemen keselamatan yang efektif bagi tenaga kesehatannya.

Sebagaimana telah disampaikan berdasarkan penelitian bahwa pentingnya perilaku pemimpin sangat mempengaruhi budaya keselamatan dalam pemberian pelayanan kesehatan. Dedikasi dari seorang pemimpin pada institusi pelayanan kesehatan akan menentukan keberhasilan keselamatan dan kesehatan kerja para tenaga kesehatan. (Bauman et al., 2012). Penelitian lainnya menjelaskan dukungan kepemimpinan dengan memberikan pelatihan pekerja dan memperkuat sistem pelaporan keselamatan kerja akan semakin meningkatkan kinerja keselamatan dalam pemberian pelayanan kesehahatan.(Yang et al., 2009)

\section{Elemen 2 : Koordinasi dan Komunikasi}

Pada elemen koordinasi dan komunikasi, memperlihatkan fasilitas pelayanan kesehatan di Provinsi Kalimantan belum semuanya berfungsi dengan baik.

Komunikasi yang akurat dan koordinasi yang tepat waktu diperlukan dalam hal memastikan analisa resiko yang telah diinformasikan dalam pengambilan keputusan. Komunikasi dan koordinasi juga memperlihatkan adanya kolaborasi yang efektif adanya kerjsama dan kepercayaan di setiap unit kerja. Komponen yang terdapat pada elemen ini tidak hanya meliputi komunikasi dan koordinasi di dalam fasilitas pelayanan kesehatan, namun juga meliputi hubungan dengan pihak lokal ataupun nasional termasuk didalamnya mengenai kondisi masyarakat maupun mengenai perawatan terhadap kesehatan primer.(WHO, 2020c)

Penelitian menyebutkan bahwa komunikasi yang dijalankan dalam yang 
digunakan untuk mengatur informasi tentang protokol diganostik cepat, tes laboratorium serta penanganan pasien merupakan salah satu faktor penentu dalam aspek manajemen rumah sakitdalam menghdapi bencana non alam. (Puji Diah, 2021)(Utami et al., 2021)

Hasil penelitian yang sejalan bahwa komunikasi adalah hal yang penting, menyatakan bahwa strategi komunikasi yang baik dapat meningkatkan kesadaran masyarakat internal dan masyarakat eksternal yang berada pda fasilitas pelayanan kesehatan terhadap Covid-19. Para tenaga kesehatan di fasilitas pelayanan kesehatan sebaiknya memiliki strategi komunikasi dan koordinasi yang ketat dan tepat dalam mengedukasi, memberi arahan dan mengingatkan selalu pentingnya protokol pelayanan yang dijalankan oleh para tenaga kesehatan. (Waridha, 2021).

\section{Elemen 3 : Surveilans dan Manajemen Informasi}

Pada elemen surveilans dan manajemen informasi, memperlihatkan fasilitas pelayanan kesehatan di Provinsi Kalimantan masih memerlukan perhatian dalam pengendalian pandemi Covid-19.

Surveilans Covid-19 adalah kegiatan yang mendasar diperlukan untuk memantau, mengendalikan wabah terutama pada lingkungan fasilitas pelayanan kesehatan. Dibutuhkan informasi terkini untuk mengetahui definisi kasus Covid-19 melalui evidence based yang muncul, sehingga fasilitas pelayanan kesehatan harus menyesuaikan dengan situasi epidemiologi yang dihadapi. (WHO, 2020c)

Manajemen informasi pada setiap fasilitas pelayanan kesehatan mempunyai peran meningkatkan kesadaran publik tentang pengawasan dan resiko yang muncul pada keadaaan pandemi Covid-19. Sesuai dengan tujuan utama surveilans covid-19 yang telah dijabarkan oleh WHO adalah untuk memantau tren Covid-19, mendeteksi kasus baru Covid-19 secara tepat, memberikan informasi epidemiologi dengan menilai resiko dan memberikan informasi epidemiologi untuk memandu kesiapsiagaan dan respon cepat terhadap Covid-19. (World Health Organization (WHO), 2020b)

Selain itu, tujuan surveilans diperbaharui terpenting adalah untuk memantau tren Covid-19, memantau penyebab utama kematian secara langsung atau tidak langsung yang disebabkan oleh Covid-19, memperkirakan morbiditas dan mortalitas tenaga kesehatan serta dapat melakukan pengendalian terhadap dampak yang kemungkinan akan terjadi. (World Health Organization (WHO), 2020c). Dengan demikian dengan melakukan surveilans pada fasilitas pelayanan kesehatan dapat meminimkan resiko buruk yang mungkin dapat dialami oleh para tenaga kesehatan yang bekerja dalam penanggulangan Covid19.

\section{Elemen 4 : Komunikasi Risiko dan Keterlibatan Masyarakat}

Pada elemen keempat yaitu komunikasi risiko dan keterlibatan masyarakat, memperlihatkan fasilitas pelayanan kesehatan di Provinsi Kalimantan belum semuanya berfungsi dengan baik.

Komunikasi risiko dan keterlibatan masyarakat dibutuhkan untuk membantu, mengatasi dan menghentikan makin banyaknya penularan wabah jika informasi yang sampaikan jelas dan akurat mengenai Covid-19. Elemen komunikasi risiko dan keterlibatan masyarakat merupakan elemen penting untuk melihat keberhasilan tanggap darurat kesehatan. Saat kondisi tanggap darurat kesehatan seperti yang saat ini terjadi yaitu pandemi Covid-19 akan menghadapi tantangan untuk dapat berkomunikasi secara efektif. Tantangan bagaimana mengkomunikasikan hal-hal yang belum pasti mengenai Covid-19 dan resiko yang dihadapi petugas kesehatan saat menangani masyrakat dengan kemungkinan hilangnya kepercayaan dan reputasi, hingga hal terburuk yaitu kematian. (WHO, 2020)

\section{Elemen 5 : Administrasi, Keuangan, dan Keberlanjutan Bisnis}

Administrasi dan keuangan merupakan sistem pendukung integral yang penting 
dalam pencegahan, persiapan dan penanggulangan keadaan darurat pandemi Covid-19. Pada elemen kelima yaitu Administrasi, Keuangan dan Keberlanjutan Bisnis, memperlihatkan ketiga rumah sakit mempunyai penilaian yang baik bertolak belakang dengan fasilitas puskesmas yang masih mempunyai penilaian kurang.

Masalah tanggap darurat Covid-19 yang dialami oleh fasilitas pelayanan kesehatan menyebabkan cash-flow keuangan menjadi tidak berjalan dengan baik, masalah yang dialami adalah kebutuhan anggaran yang besar dalam menyediakan sarana dan prasarana pelayanan Covid-19 dan biaya pelayanan kesehatan meningkat dikarenakan penataan ulang pelayanan kesehatan. (Bartsch et al., 2020)

Dari sisi administrasi elemen ini menerangkan bahwa fasilitas pelayanan kesehatan harus memiliki manajemen klinis Covid-19, prosedur kelayakan perawatan pasien yang aman baik di rumah sakit, perawatan yanga aman dan sistem rujukan yang memperhatikan akses pasien ke fasilitas pelayanan keehatan.(WHO, 2020)

\section{Elemen 6 : Sumber Daya Manusia}

Sumber daya manusia adalah sumber daya yang penting untuk pencegahan, persiapan dan penanggulanganan wabah pandemi Covid-19. Perlu diperhatikan pada setiap fasislitas pelayanan kesehatan untuk memastikan memiliki staf yang memadai dan memiliki kemampuan yang memadai.

Pada elemen keempat yaitu sumber daya manusia, memperlihatkan fasilitas pelayanan kesehatan di Provinsi Kalimantan sudah cukup baik di beberapa fasilitas pelayanan kesehatan, walau masih ada yang bernilai kurang pada fasilitas pelayanan kesehatan lainnya.

Tenaga kesehatan adalah garda terdepan dalam penanganan Covid-19 dengan resiko bahaya yang dapat mengancam termasuk paparan pathogen, jam kerja yang panjang, tekanan psikologis, kelelahan yang besar, stigma masyarakat dan resiko kekerasan. Setiap fasilitas pelayanan kesehatan bertanggungjawab atas hak para tenaga kesehatan dan melindungi keselamatan dan kesehatan kerja.

Sesuai dengan penelitian telah ditemukan gejala depresi ditemukan pada tenaga kesehatan sebanyak 50,4\%, kecemasan pada tenaga kesehatan sebanyak 44,6\%, insomnia yang dialami oleh tenaga keseahatan sebanayak $34 \%$ dan tenaga kesehatan mengalami distress sebanyak 71,5\%. (Lai et al., 2020)

Penelitian lainnya menyebutkan bahwa kondisi psikologis yang dialami oleh tenaga kesehatan selama pandemi Covid-19 belum menjadi fokus utama pemerintah di berbagai negara. Penyebab stress pada tenaga kesehatan dikarenakan oleh beban pekerjaan yang tinggi, stigma dan kekhawatiran akan terinfeksi Covid-19. (Handayani, 2020)

Fasilitas pelayanan kesehatan sebaiknya memperhatikan hak-hak para tenaga kerja dengan melakukan pemastian bahwa adanya tindakan pencegahan serta perlindungan yang dibutuhkan untuk meminimalkan hal hal yang mengancam keselamatan dan kesehatan pada tenaga kesehatan, memberikan pelatihan yang dibutuhkan dalam memberikan pelayanan, pelatihan meliputi prosedur pelayanan, dan pelatihan terkait keselamatan dan kesehatan kerja, memberikan pelatihan terkait pencegahan dan pengendalian infeksi, memberikan pelatihan terkait bagaimana menggunakan, melepaskan dan membuang alat pelindung diri, memberikan fasilitas yang tepat terkait adanya pembaruan teknis Covid19, menyediakan lingkungan yang aman untuk dapat melaporkan insiden yang terjadi, dan lingkungan yang aman dari kasus kekerasan. (World Health Organization (WHO), 2020a)

\section{Elemen 7 : Surge Capacity}

Pada elemen keempat yaitu surge capacity, elemen ini hanya menyoroti fasilitas pelayanan kesehatan di rumah sakit, terlihat nilai elemen ini rumah sakit masih memiliki nilai yang belum cukup di Provinsi Kalimantan.

Pada elemen ini, rumah sakit diharapkan dapat mempersiapkan dalam menghadapi lonjakan yang mungkin saja terjadi akibat 
keadaan darurat Covid-19. Layanan dan perrlengkapan yang diperlukan menjadi penting diperhatikan dalam mengatasi resiko Covid-19 yang mencakup perawatan yang dibutuhkan terutama pada pasien yang mempunyai gejala berat dan akut, dengan tetap memperhitungkan beban tenaga kesehatan yang dibutuhkan dan menjaga keselamatan para garda terdepan tersebut.

\section{Elemen 8 : Keberlanjutan Layanan Pendukung Esensial}

Pada elemen keberlanjutan layanan pendukung terlihat tidak semua fasilitas pelayanan kesehatan memiliki nilai yang baik di Provinsi Kalimantan. Elemen ini terkait dengan kesiapan secara operasional meliputi perawatan medis yang berkesinambungan.

Oleh karena itu setiap failitas pelayanan kesehatan sebaiknya dapat mempertimbangkan cara yang terbaik dalam mempertahankan keberlanjutan layanan kesehatan.

Berdasarkan panduan WHO, untuk keberlanjutan perlu diperhatikan kategori pelayanan dengan priotitas meliputi pemberian vaksinasi, pelayanan kehamilan dan persalinan, perawatan populasi rentan, penyediaan obat-obatan dan pengelolaan berkelanjutan untuk penyakit kronis, terapi rawat inap kritis, manajemen konisi kesehatan darurat dan layanan penunjang lainnya.

Jika periode lonjakan tinggi terjadi, pihak fasilitas pelayanan kesehatan perlu mempertimbangkan kembali waktu yang tepat untuk melakukan strategi untuk pemulihan layanan yang komprehensif dan efektif dengan meninjau kembali secara berkala saat angka wabah makin tinggi. (WHO, 2020)

\section{Elemen 9 : Manajemen Pasien}

Elemen Manajemen Pasien pada fasilitas pelayanan kesehatan di Privinsi Kalimantan Timur masih perlu mendapatkan perhatian agar dapat memberikan pelayanan yang prima untuk pasien yang membutuhkan.
Manajemen pasien meliputi penerimaan atau rujukan pasien, pelayanan triase, penegakan diagnosa, pengobatan, alur pasien, tracing, tindak lanjut, pelayanan penunjang, pelayanan kefarmasian, dan logistik.

Tujuan adanya manajemen pasien bermaksud untuk, Memastikan memiliki sistem yang aman, efektif dan efisien dan Memastikan sumber daya manusia tetap dalam keadaan aman walau terdapat lonjakan pasien

\section{Elemen 10 : Kesehatan Kerja, Kesehatan Mental, dan Dukungan Psikososial}

Elemen Kesehatan Kerja, Kesehatan Mental dan Dukungan Psikososial pada fasilitas pelayanan kesehatan di Provinsi Kalimantan Timur juga masih beberapa yang mempunyai nilai yang kurang.

Kesehatan Kerja, Kesehatan Mental dan Dukungan psikososial dibutuhkan untuk mengurangi dampak psikologis dan sosial yang dapat yang merugikan pasien, dan tenaga kesehatan yang bertugas.

Penelitian menunjukan ada beberapa ketidaksesuaian penerapan keselamatan dan kesehatan kerja di fasilitas pelayanan kesehatan dalam hal penyediaan sarana prasarana perawatan Covid-19 yang digunakan atau yang dibutuhkan oleh tenaga kesehatan. Banyak tenaga kesehatan menggunakan sarana prasarana dibawah standar dari yang seharusnya saat bekerja. Tidak sedikit dari tenaga kesehatan memperpanjang pemakaian atau bahkan membeli sendiri keperluan tersebut dikarenakan terbatasnya sumber daya terutama keuangan. Hal tersebut akan beresiko kepada tenaga kesehatan yang akan dengan mudah terpapar virus, yang pada akhirnya akan meningkatkan resiko kesehatan tenaga kesehatan yang akan menjadi beban lebih besar keuangan. (Prajogo et al., 2020)

Hasil penelitian menyebutkan $37,5 \%$ para tenaga kesehatan merasa terbebani dengan pekerjaan yang dilakukan saat masa Pandemi. Rangkuman hasil penelitian juga mengungkapkan bahwa hanya $64,3 \%$ tenaga kesehatan mendapatkan dukungan sosial dari keluarga atau teman. Dengan kesimpulan 
lainnya bahwa dukungan sosial yang rendah adalah penyebab stres utama para tenaga kesehatan dalam mengupayakan pelayanan terbaik walaupun sedang menghadapi kondisi yang tidak pernah pasti dan berbahaya bagi kesehatan dan keselamatannya. (Tamara \& Wulandari, 2021)

\section{Elemen 11 : Identifikasi dan Diagnosis Cepat}

Elemen Identifikasi dan Diagnosis Cepat pada fasilitas pelayanan kesehatan di Provinsi Kalimantan Timur juga masih beberapa yang mempunyai nilai yang kurang.

Kesulitan utama ketika melakukan uji diagnostik tes cepat yang shahih yaitu memastikan negatif palsu, hal ini dikarenakan angka deteksi virus pada rRTPCR sebagai baku emas tidak ideal. Angka fatalitas kasus (CFR) bergantung pada ketersediaan layanan kesehatan, usia dan masalah kesehatan dalam populasi, dan jumlah kasus yang tidak terdiagnosis. (Susilo et al., 2020)

Metode yang dianjurkan dalam deteksi virus adalah amplifikasi asam nukleat dengan real-time reversetranscription polymerase chain reaction (rRT-PCR) dan dengan sequencing. Sehingga sampel dikatakan terkonfirmasi positif jika rRT-PCR Positif pada minimal dua target genom (N,E,S, atau RdRP) yang spesifik SARS$\mathrm{CoV}-2 ; \quad$ atau rRT-PCR positif betacoronavirus, ditunjang hasil sequencing sebagian atau seluruh genom virus yang sesuai dengan SARS-CoV-2. (Tim Kerja Kementerian Dalam Negeri, 2020)

\section{Elemen 12 : Pencegahan dan Pengendalian Infeksi}

Elemen Pencegahan dan Pengendalian Infeksi Identifikasi di setiap fasilitas pelayanan kesehatan di Provinsi Kalimantan Timur berdasarkan penilaian skor menunjukan nilai yang sangat bagus, ini menggambarkan setiap fasilitas pelayanan kesehatan telah terlaksana dengan sangat baik.
Dari penelitian yang ada dan menjadi catatan pada pelaksanaan elemen pencegahan dan pengendalian infeksi yang menjadi perhatian khusus adalah kewaspadaan isolasi (kewaspadaan standar dan kewaspadaan transmisi) dengan memperhatikan ketersediaan sarana dan prasarana pada kewaspadaan standar dengan menyesuaikan pada kebijakan pemerintah yaitu melalui KMK No. HK.01.07/MENKES/413/2020, pengendalian administrasi yang dijalankan dengan memberlakukan protokol kesehatan pada semua arena fasilitas pelayana kesehatan, melakukan pelarangan pengunjung dan penunggu pasien pada kasus Covid-19, mengorganisir alat pelindung diri, agar persediaan dan penggunaannya dapat digunakan dengan benar, serta membuat kebijakan berkaitan dengan kesehatan dan perlindungan pegawai, pendidikan dan pelatihan yang diberikan secara berkala dan update ilmu terkini berkaitan dengan Covid19 dengan tujuan setiap pegawai sadar dan pencegahan dan pengendalian rujukan dilakukan dalam mengatur, mentransfer dan menerima pasien dengan kecurigaan atau terkonfirmasi Covid-19 dengan mengatur protokol penerimaan, mentransfer pasien, serta mengatur petugas ambulan serta pencegahan dan pengendalian untuk pemulasaraan pasien Covid-19 dikelola dengan etis dan layak sesuai dengan agama, nilai norma, budaya dan prinsip utama dalam memberikan pelayanan dilakukan sesuai dengan standar sarana dan prasarana yang memadai.(Ismail et al., 2021)

\section{KESIMPULAN}

Secara keseluruhan, fasilitas pelayanan kesehatan di Provinsi Kalimantan Timur telah megimplementasikan semua yang tertuang pada KMK 327 tentang Penetapan Corona Virus Disease 2019 (Covid-19) Akibat Kerja sebagai Penyakit Akibat Kerja yang Spesifik pada Pekerjaan Tertentu dan berdasarkan KMK 413 tentang Pedoman Pencegahan dan Pengendalian Coronavirus Diseases 2019 (Covid-19). 
Upaya-upaya pencegahan dan pengendalian COVID-19 sudah diterapkan dengan baik pada fasilitas pelayanan kesehatan pada tingkat rumah sakit, puskesmas dan labobaratorium. Elemen kesehatan kerja, kesehatan mental dan dukungan psikososial serta administrasi, keuangan dan keberlanjutan bisnis merupakan elemen yang harus ditingkatkan dari setiap rumah sakit, puskesmas dan laboratorium.

Upaya-upaya pencegahan dan pengendalian COVID-19 diperlukan peningkatan yang lebih baik dan dilakukan monitoring yang berkelanjutan dengan memperhatikan kendala-kendala yang terjadi pada setiap elemen yang menjadi acuan sesuai dengan KMK 327 dan KMK 413.

\section{UCAPAN TERIMA KASIH}

Penelitian ini memberikan penghargaan setinggi-tingginya kepada semua pihak fasillitas pelayanan kesehatan di Provinsi Kalimantan Timur yang telah berpartisipasi dalam terlaksananya penelitian ini. Penelitian ini dilaksanakan oleh Mahasiswa danPerhimpunan Ahli Kesehatan Kerja Indonesia (PAKKI) dengan anggaran dari Direktorat Kesehatan Kerja dan Olahraga Kementerian Kesehatan Republik Indonesia.

\section{DAFTAR PUSTAKA}

Apriningsih, H., Prabowo, N. A., Myrtha, R., Gautama, C. S., \& Wardani, M. M. (2020). PREVENTION OF TRANSMISSION OF COVID-19 IN HEALTH WORKERS IN. Jurnal Ilmiah Pengabdian Kepada Masyarakat, 4(2), 556-564. file:///C:/Users/W8imdoows 2/Downloads/admin-oamjms-t1-45.pdf

Bartsch, B. S. M., Ferguson, M. C., Mckinnell, J. A., Shea, K. J. O., Wedlock, P. T., Siegmund, S. S., \& Lee, B. Y. (2020). The Potential Health Care Costs And Resource Use Associated With COVID-19 In The United States. Health Affairs, 6, 927-935. https://doi.org/https://doi.org/10.1377/hlth aff. 2020.00426

Bauman, A., Holnes, D. L., Norman, P., \& Wheeler, Dina Idriss, Boucher, P. (2012).
The Ergonomic Program Implementation Continuum (EPIC): integration of health and safety--a process evaluation in the healthcare sector. Journal of Safety Research, 43(3), 205-213. https://doi.org/https://doi.org/10.1016/j.jsr. 2012.07.003

Deyulmar, B. A., Suroto and Wahyuni, I. (2018) 'Analysis of Factors Associated with Fatigue in Opak Crackers in Ngadikerso Village, Semarang City, Jurnal Kesehatan Masyarakat, 6(4), pp. 278-285.

Gurusinga, D., Camelia, A. and Purba, I. G. (2015) 'Analysis of Associated Factors with Work Fatigue at Sugar Factory Operators PT. PN VII Cinta Manis in 2013', Jurnal Ilmu Kesehatan Masyarakat, 6(2), pp. 83-91.

Handayani, et al. (2020). Faktor penyebab stres pada tenaga kesehatan dan masyarakat saat pandemi covid-19. Jurnal Keperawatan Jiwa, 8(3), 353-360. file:///C:/Users/W8IMDO 1/AppData/Loc al/Temp/5990-14532-1-PB.pdf

Ismail, J., Health, R. A.-J. of M. C., \& 2021, undefined. (2021). Implementasi Pencegahan Dan Pengendalian Infeksi Covid-19 Di RSUD Salewangang Kabupaten Maros. Pasca-Umi.Ac.Id, 2(3), 95-116. http://pascaumi.ac.id/index.php/jmch/article/view/550

Kemenkes. (2021). Situasi Terkini Perkembangan Coronavirus Disease (COVID-19). Www.Covid19.Go.Id. https://covid19.kemkes.go.id/document/sit uasi-terkini-perkembangan-coronavirusdisease-covid-19-5-agustus-2021/view

Lai, J., Ma, S., Wang, Y., Cai, Z., Hu, J., Wei, N., Wu, J., Du, H., Chen, T., \& Li, R. (2020). Factors Associated With Mental Health Outcomes Among Health Care Workers Exposed to Coronavirus Disease 2019. JAMA Network Open, 3(3), 1-12. https://doi.org/10.1001/jamanetworkopen.2 020.3976

Minister of Manpower Regulation (2018) Number 5 Year 2018. Concerning Safety and Health. Jakarta: Ministry of Manpower Republic of Indonesia.

Nugroho, B., \& Damayanti, I. (2019). Jokowi announces Indonesia's new capital in East Kalimantan. Nikkei Asia. https://asia.nikkei.com/Politics/Jokowi- 
announces-Indonesia-s-new-capital-inEast-Kalimantan

Paramita, S., Rahmadi, A., Isnuwardana, R., \& Nugroho, R. A. (2020). One-month Progress of COVID-19 Cases in East Kalimantan , Indonesia. Macedonian Journal of Medical Sciences, 8(Coronavirus Disease (COVID-19)), 4550. file:///C:/Users/W8imdoows 2/Downloads/admin-oamjms-t1-45.pdf

Prajogo, D., Sohal, A., Dwei, R. S., Shanti, D., Sudiarno, A., Widyaningrum, R., Rahman, A., Sebastian, E., \& Brown, H. (2020). Kesehatan dan Keselamatan Kerja ( K3 ): Melindungi Tenaga Kesehatan Indonesia Selama Pandemi. In The AustraliaIndonesia Centre (pp. 1-28). Kemitraan Riset Australia-Indoneseia (PAIR).

Satgas, C. (2021). Peta Sebaran COVID-19. 7 Agustus 2021. https://covid19.go.id/petasebaran-covid19

Susilo, A., Rumende, C. M., Pitoyo, C. W., Santoso, W. D., Yulianti, M., Herikurniawan, H., Sinto, R., Singh, G., Nainggolan, L., Nelwan, E. J., Chen, L. K., Widhani, A., Wijaya, E., Wicaksana, B., Maksum, M., Annisa, F., Jasirwan, C. O. M., \& Yunihastuti, E. (2020). Coronavirus Disease 2019: Tinjauan Literatur Terkini. Jurnal Penyakit Dalam Indonesia, $\quad 7(1), \quad 45$. https://doi.org/10.7454/jpdi.v7i1.415

Tamara, T. A., \& Wulandari, R. D. (2021). Differences as a Work Stress Factors Causing on Healthcare Personnel Due to the Covid-19 Pandemic: A Narrative L. Jurnal Ilmu Kesehatan Masyarakat, 17(1). https://doi.org/10.19184/ikesma.v17i1.218 92

Tim Kerja Kementerian Dalam Negeri. (2020). Pedoman Umum Menghadapi Pandemi Covid-19 Bagi Pemerintah Daerah: Pencegahan, Pengendalian, Diagnosis dan Manajemen. Journal of Chemical Information and Modeling, 53(9), 16891699.

https://doi.org/10.1017/CBO97811074153 24.004

Utami, Y. P. D., Pinzon, R. T., \& Meliala, A. (2021). Evaluasi Kesiapan Rumah Sakit Menghadapi Bencana Non-Alam: Studi Kasus COVID-19 di Rumah Sakit Bethesda Yogyakarta. Jurnal Kebijakan
Kesehatan Indonesia: JKKI, 10(2), 100106.

https://journal.ugm.ac.id/jkki/article/view/6 1686

Waridha, M. R. (2021). Strategi komunikasi kesehatan rumah sakit islam malahayati dalam meningkatkan kesadaran masyarakat tentang covid-19 [UNIVERSITAS MUHAMMADIYAH SUMATERA UTARA MEDAN]. http://repository.umsu.ac.id/bitstream/1234 56789/15177/1/Muhammad Rivan Waridha.pdf

WHO. (2017). Emergency Response Framework. In $W H O$ (Vol. 76).

WHO. (2020a). Home care for patients with suspected or confirmed COVID-19 and management of their contacts (Issue August). WHO. https://www.who.int/publications-detail/

WHO. (2020b). Operational guidance for maintaining essential health services during an outbreak (Issue March, pp. 114).

WHO. (2020c). Rapid Hospital Readiness Checklist (pp. 1-20). WHO/2019nCoV/hospital_readiness_checklist/2020.1

WHO. (2020d). Risk communication and community engagement ( RCCE ) readiness and response to the 2019 novel (Issue January). WHO. https://apps.who.int/iris/bitstream/handle/1 0665/330678/9789240000773eng.pdf? sequence $=1 \&$ isAllowed $=y$

World Health Organization (WHO). (2020a). Coronavirus disease ( COVID-19) outbreak: rights, roles and responsibilities of health workers, including key considerations for occupational safety and health (Issue March, pp. 1-2). WHO. https://apps.who.int/iris/bitstream/handle/1 0665/331510/WHO-2019-nCov-

HCWadvice-2020.2eng.pdf? sequence $=1 \&$ isAllowed $=y$

World Health Organization (WHO). (2020b). Global Surveillance for COVID-19 caused by human infection with COVID-19 virus: interim guidance. Who, March, 1-4. https://www.who.int/publicationsdetail/global-surveillance-for-humaninfection-with-novel-coronavirus-(2019ncov)

World Health Organization (WHO). (2020c). 
Public health surveillance for COVID-19. https://doi.org/10.1007/978-1-59745-326-

4_13

Xiang, Y.-T., Yang, Y., Li, W., Zhang, L., Zhang, Q., Cheung, T., \& Ng, C. (2020). Timely Mental Health Care for The 2019 Novel Coronavirus Outbreak is Urgently Needed. Lancet Psychiatry, 7(3)(January), 228-229. https://doi.org/10.1016/S22150366(20)30046-8

Yang, C.-C., Wang, Y.-S., Chang, S.-T., Guo, S.E., \& Huang, M.-F. (2009). A study on the leadership behavior, safety culture, and safety performance of the healthcare industry. World Academy of Science, Engineering and Technology, 53(1), 11481155.

Zhu, N; Zhang, D; Wang, W. (2019). A Novel Coronavirus from Patients with Pneumonia in China. $N$ Engl J Med, 382(8), 727-733. https://doi.org/10.1056/NEJMoa2001017 